\title{
The utilization of lysine by young pigs from nine protein concentrates compared with free lysine in young pigs fed ad lib.
}

\author{
BY JANE LEIBHOLZ \\ Department of Animal Husbandry, University of Sydney, Camden, \\ New South Wales 2570, Australia
}

(Received 31 December 1984 - Accepted 2 August 1985)

\begin{abstract}
1. Pigs ( $n$ 195) between 21 and $49 \mathrm{~d}$ of age were given a basal diet containing wheat, wheat gluten and cotton-seed meal which was supplemented with one of nine protein concentrates or free L-lysine. The diets were given ad lib. in two experiments.

2. Increasing the lysine content of the diets from 6.9 to $10.1 \mathrm{~g} / \mathrm{kg}$ increased the weight gains of the pigs from 89 to $317 \mathrm{~g} / \mathrm{d}$ in the first experiment. In the second experiment the weight gains were increased from $68 \mathrm{go} 213 \mathrm{~g} / \mathrm{d}$ by increasing the lysine content of the diets from 5.9 to $9.5 \mathrm{~g} / \mathrm{kg}$.

3. The utilization of lysine from the protein concentrates was compared with the utilization of free L-lysine.

4. The utilization of lysine for weight gain compared with free lysine was $0.86-0.88$ for meat meals, $0.95-0.99$ for soya-bean meal, 0.69-0.75 for cotton-seed meal, 0.90 for lupins (Lupinus augustifolius) and 0.99 for milk.
\end{abstract}

The US National Research Council (1979) summarized the lysine requirement of pigs, $5-10 \mathrm{~kg}$ live weight, as $9.5 \mathrm{~g} / \mathrm{kg}$ diet. A higher requirement was suggested by the UK Agricultural Research Council (1981), 0.98 g/MJ digestible energy (DE), which is equivalent to about $14 \mathrm{~g}$ lysine $/ \mathrm{kg}$ diet. This difference in the estimates of the lysine requirements of young pigs is due to the range of the results in the literature. These variations may be attributed to large differences in the utilization of lysine from various sources of protein. Other factors such as the amino acid balance of the diets and their energy content could also affect the estimate.

In growing pigs, there is information showing that protein concentrates can vary in their availability of lysine as measured by slope-ratio assays, with a range $0.50-0.88$ for weight gain (Batterham et al. 1979). No estimates of the digestibility of lysine were made in these experiments, but Alimon \& Farrell (1980) found the apparent digestibility to the terminal ileum of similar protein concentrates was $0 \cdot 72-0 \cdot 84$. The apparent digestibility of lysine to the ileum of young pigs has been reported to range from 0.54 to 0.75 (Leibholz, 1985).

In the present experiment, the utilization of lysine from several protein concentrates was measured in pigs $21-49 \mathrm{~d}$ of age. The response in weight gain, feed conversion ratio and nitrogen retention to increasing lysine content from nine protein concentrates was related to the performance of pigs given free lysine. The results were compared with earlier estimates of the apparent digestibility of lysine (Leibholz, 1985).

\section{EXPERIMENTAL}

\section{Animals and management}

Expt 1. Four similar groups of twenty-one Large White $\times$ Landrace male pigs were taken from the sows between 17 and $18 \mathrm{~d}$ of age. The pigs were housed in tiered cages in groups of seven for a preliminary period of $2-3 \mathrm{~d}$, during which time they were offered pelleted food.

At $21 \mathrm{~d}$ of age, pigs were randomly allocated, one per cage, to the experimental diets shown in Table 1. Four pigs were allocated to each diet, that is, each level of lysine for each protein source. Diets were offered ad lib., fresh food was offered daily and wastage was weighed weekly. Water was provided by nipple drinkers. The pigs were weighed weekly. 
Table 1. Composition $(\mathrm{g} / \mathrm{kg})$ of basal diets

\begin{tabular}{lrr}
\hline & Expt 1 & Expt 2 \\
\hline Wheat & 522 & 532 \\
Cotton-seed meal & 140 & 140 \\
Wheat gluten & 90 & 80 \\
Maize starch & 200 & 200 \\
Methionine & 2 & 2 \\
Calcium dihydrogen phosphate & 36 & 36 \\
Salt & 5 & 5 \\
& 5 & 5 \\
\hline
\end{tabular}

* Vitamin and mineral supplement supplying (mg/kg diet): 1.5 retinol, 0.025 cholecalciferol, $20 \alpha$-tocopherol, $20 \mu \mathrm{g}$ cyanocobalamin, 4 riboflavin, 20 niacin, 10 pantothenic acid, $0 \cdot 1$ biotin, 100 iron, 10 copper, 40 manganese, 50 zinc; other additives $(\mathrm{mg} / \mathrm{kg}$ diet $): 100$ ethoxyquin, 50 oxytetracycline.

The cages were in a controlled-environment room maintained at $26^{\circ}$. No mortalities occurred during the experiment which was of $28 \mathrm{~d}$ duration.

Expt 2. Three similar groups of thirty-seven Large White $\times$ Landrace male pigs were taken from the sows between 17 and $18 \mathrm{~d}$ of age and treated as in Expt 1 . The pigs were randomly allocated, one per cage, to the experimental diets shown in Table 1. Three pigs were allocated to each diet.

Faeces were collected on screens above sloping trays, which drained the urine into bottles containing hydrochloric acid $(5 \mathrm{M})$. The collections were made from $43-49 \mathrm{~d}$ of age.

\section{Diets}

The basal diet contained wheat, wheat gluten and cotton-seed meal. Four protein concentrates were assayed in Expt 1 and five protein concentrates in Expt 2. For the control diets, the basal diet (Table 1) was supplemented with free L-lysine hydrochloride. The levels of lysine inclusion from the protein supplements and free L-lysine are shown in Tables 3 and 4. (pp. 182 and 183). The supplements replaced the maize starch in the basal diet on an equal weight basis.

The amino acid composition of the dietary ingredients is shown in Table 2.

\section{Chemical analysis}

Dry matter and organic matter of food and faeces were determined after drying in a forced-air oven at $95^{\circ}$ for $24 \mathrm{~h}$ and ashing for $6 \mathrm{~h}$ at $550^{\circ}$ respectively. Total $\mathrm{N}$ in feed, faeces and urine was determined by the Kjeldahl method. Amino acids in the feeds were determined using ion-exchange chromatography (TSM Amino Acid AutoAnalyzer; Technicon Equipment Ltd, Sydney). Samples were hydrolysed in $6 \mathrm{M}-\mathrm{HCl}$ for $24 \mathrm{~h}$ at $110^{\circ}$.

\section{Statistical analysis}

Previous work of this type has used slope ratio assay analysis but it was considered to be inappropriate in this case. A major requirement of slope-ratio analysis is that the lines fitted to the 'reference' and 'treatment' have a common intercept at the basal level and, in general, this was not the case in this experiment. For each lysine source, linear regressions were fitted with lysine intake as the independent variable and live-weight gain as the dependent variable. Lysine utilization was measured by the regression coefficient ratio, free lysine:protein-based lysine and the standard deviation of the ratio was calculated in the usual way (Kendall \& Stuart, 1977) (Table 5, p. 184). The values from the basal diet were 


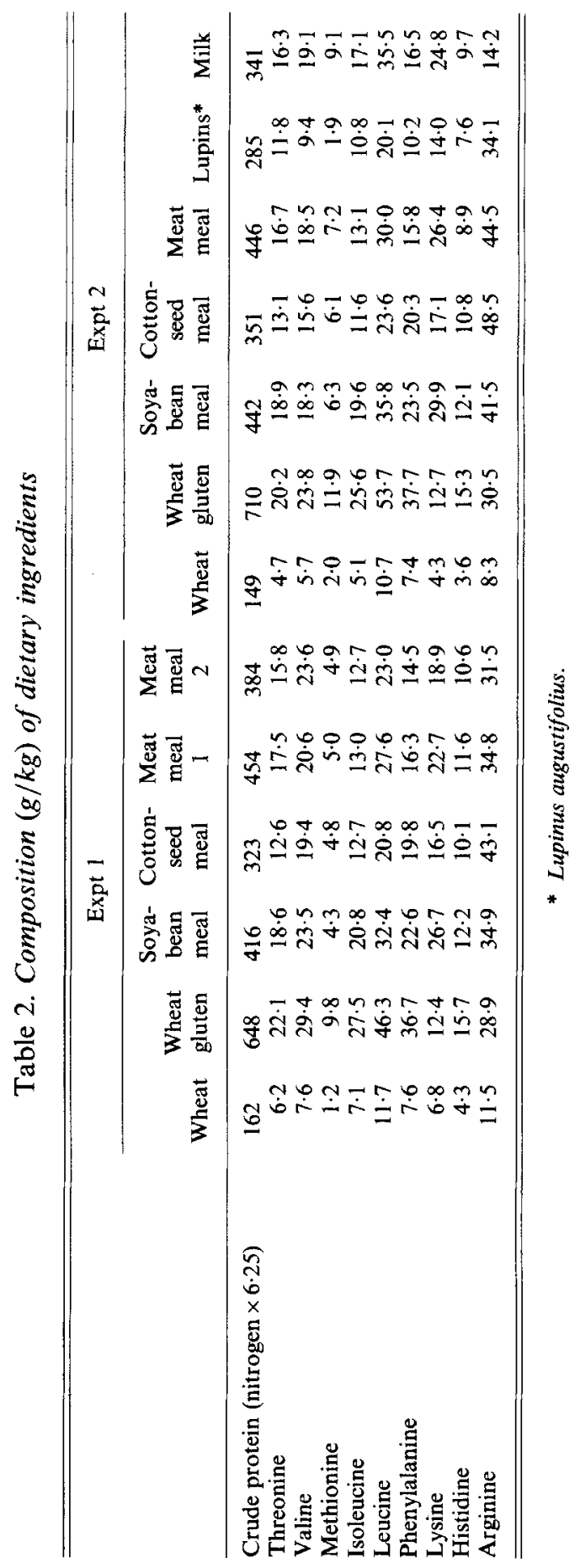


Table 3. Expt 1. Performance of pigs from 21 to 49 d of age given diets containing free lysine or one of five protein concentrates at five levels of inclusion of lysine

\begin{tabular}{|c|c|c|c|c|c|c|c|}
\hline & \multirow[b]{2}{*}{$\begin{array}{l}\text { Lysine } \\
\text { in diet } \\
(\mathrm{g} / \mathrm{kg})\end{array}$} & \multicolumn{5}{|c|}{ Lysine source } & \multirow[b]{2}{*}{ Mean } \\
\hline & & $\begin{array}{l}\text { Free } \\
\text { lysine }\end{array}$ & $\begin{array}{l}\text { Soya- } \\
\text { bean } \\
\text { meal }\end{array}$ & $\begin{array}{l}\text { Cotton- } \\
\text { seed } \\
\text { meal }\end{array}$ & $\begin{array}{c}\text { Meat } \\
\text { meal } \\
1\end{array}$ & $\begin{array}{l}\text { Meat } \\
\text { meal } \\
2\end{array}$ & \\
\hline \multirow[t]{7}{*}{ Wt gain $(g / d)$} & 6.9 & 89 & - & - & - & - & 89 \\
\hline & $7 \cdot 7$ & 175 & 194 & 161 & 178 & 190 & 179 \\
\hline & 8.5 & 261 & 269 & 158 & 221 & 230 & 244 \\
\hline & $9 \cdot 3$ & 306 & 287 & 189 & 268 & 300 & 269 \\
\hline & 10.1 & 323 & 316 & 270 & 345 & 332 & 317 \\
\hline & Mean & 231 & 231 & 173 & 220 & 226 & \\
\hline & SEM & & & $13 \cdot 3$ & & & \\
\hline \multirow[t]{7}{*}{ Feed conversion ratio } & 6.9 & $3 \cdot 32$ & - & - & - & - & $3 \cdot 32$ \\
\hline & 7.7 & 2.07 & 1.84 & $2 \cdot 12$ & 2.09 & $2 \cdot 15$ & 2.05 \\
\hline & 8.5 & 1,90 & 1.67 & $2 \cdot 11$ & 1.82 & 1.82 & 1.86 \\
\hline & $9 \cdot 3$ & 1.70 & 1.71 & 1.88 & 1.70 & 1.68 & 1.75 \\
\hline & $10 \cdot 1$ & 1.59 & 1.57 & $1 \cdot 80$ & 1.66 & $1 \cdot 68$ & 1.66 \\
\hline & Mean & $2 \cdot 12$ & $2 \cdot 02$ & $2 \cdot 25$ & $2 \cdot 12$ & $2 \cdot 13$ & \\
\hline & SEM & & & 0.047 & & & \\
\hline
\end{tabular}

included only in the free lysine regression as it is not valid to include the same values in the estimate of two parameters that are to be compared.

The values in Tables 3 and 4 were subjected to analysis of variance, and least significant differences $(P<0.05)$ were used to compare means (Steel \& Torrie, 1960).

\section{RESULTS}

There was a linear response in weight gain, feed conversion ratio and $\mathrm{N}$ retention as the lysine content of the diets increased from $6.9 \mathrm{~g} / \mathrm{kg}$ to $10.1 \mathrm{~g} / \mathrm{kg}$ in Expt 1 (Table 3) and $5.9 \mathrm{~g} / \mathrm{kg}$ to $9.5 \mathrm{~g} / \mathrm{kg}$ in Expt 2 (Table 4) with all nine protein concentrates and free lysine. The requirement for all essential amino acids except lysine (US National Research Council, 1979) were met by all diets.

The relative utilization of lysine from cotton-seed meal for weight gain was significantly less $(P<0.05)$ than that from free lysine and soya-bean meal in Expt 1 (Table 5). In Expt 2 , the utilization of lysine from cotton-seed meal for weight gain was lower relative to the utilization of lysine from free lysine and all other protein concentrates. The utilization of lysine from meat meal for weight gain tended to be less than that from free lysine, milk and soya-bean meal but the differences were not significant. Responses to lysine from the other protein concentrates and free lysine were similar for both feed conversion ratio and weight gain.

$\mathrm{N}$ retention was measured in the second experiment and, as shown in Table 5, the utilization of lysine from meat meal and cotton-seed meal was less than that of free lysine. The utilization of lysine from cotton-seed meal was also less than that from soya-bean meal, lupins and milk. 
Table 4. Expt 2. Performance of pigs from 21 to $49 \mathrm{~d}$ of age given diets containing free lysine or one of five protein concentrates at five levels of inclusion of lysine

\begin{tabular}{|c|c|c|c|c|c|c|c|c|}
\hline & \multirow[b]{2}{*}{$\begin{array}{l}\text { Lysine } \\
\text { in diet } \\
(\mathrm{g} / \mathrm{kg})\end{array}$} & \multicolumn{7}{|c|}{ Lysine source } \\
\hline & & $\begin{array}{l}\text { Free } \\
\text { lysine }\end{array}$ & $\begin{array}{l}\text { Soya- } \\
\text { bean } \\
\text { meal }\end{array}$ & $\begin{array}{l}\text { Cotton- } \\
\text { seed } \\
\text { meal }\end{array}$ & $\begin{array}{l}\text { Meat } \\
\text { meal }\end{array}$ & Lupins* & Milk & Mean \\
\hline \multirow[t]{9}{*}{ Wt gain $(g / d)$} & 5.9 & 68 & - & 一 & - & - & - & 68 \\
\hline & $6 \cdot 5$ & 116 & 93 & 91 & 95 & 97 & 91 & 97 \\
\hline & $7 \cdot 1$ & 129 & 116 & 102 & 117 & 124 & 92 & 113 \\
\hline & $7 \cdot 7$ & 137 & 134 & 99 & 127 & 143 & 148 & 131 \\
\hline & $8 \cdot 3$ & 163 & 168 & 103 & 166 & 214 & 165 & 163 \\
\hline & 8.9 & 195 & 199 & 131 & 195 & 200 & 221 & 190 \\
\hline & $9 \cdot 5$ & 240 & 233 & 144 & 189 & 225 & 244 & 213 \\
\hline & Mean & 150 & 144 & 105 & 137 & 153 & 147 & \\
\hline & SEM & & & & $10 \cdot 8$ & & & \\
\hline \multirow[t]{9}{*}{ Feed conversion ratio } & 5.9 & $3 \cdot 26$ & - & - & - & - & - & $3 \cdot 26$ \\
\hline & $6 \cdot 5$ & $2 \cdot 38$ & $2 \cdot 60$ & $2 \cdot 90$ & $2 \cdot 66$ & $2 \cdot 72$ & $2 \cdot 60$ & $2 \cdot 64$ \\
\hline & $7 \cdot 1$ & $2 \cdot 30$ & $2 \cdot 80$ & $2 \cdot 66$ & $2 \cdot 46$ & $2 \cdot 36$ & $2 \cdot 41$ & $2 \cdot 53$ \\
\hline & $7 \cdot 7$ & $2 \cdot 22$ & $2 \cdot 33$ & $2 \cdot 49$ & $2 \cdot 19$ & $2 \cdot 18$ & $2 \cdot 23$ & $2 \cdot 27$ \\
\hline & $8 \cdot 3$ & $2 \cdot 05$ & $2 \cdot 04$ & $2 \cdot 72$ & $2 \cdot 15$ & $2 \cdot 01$ & 1.93 & $2 \cdot 15$ \\
\hline & $8 \cdot 9$ & $2 \cdot 00$ & 1.68 & $2 \cdot 70$ & $2 \cdot 01$ & 2.09 & $1 \cdot 70$ & 2.03 \\
\hline & $9 \cdot 5$ & 1.95 & 1.76 & $2 \cdot 31$ & $2 \cdot 00$ & $1 \cdot 73$ & $1 \cdot 85$ & 1.92 \\
\hline & Mean & $2 \cdot 32$ & $2 \cdot 36$ & $2 \cdot 72$ & $2 \cdot 39$ & $2 \cdot 33$ & $2 \cdot 29$ & \\
\hline & SEM & & & & 0.091 & & & \\
\hline \multirow[t]{9}{*}{ Nitrogen retention $(\mathrm{g} / \mathrm{d})$} & $5 \cdot 9$ & $1 \cdot 5$ & - & - & 一 & - & - & $1 \cdot 5$ \\
\hline & $6 \cdot 5$ & $5 \cdot 1$ & $4 \cdot 1$ & $3 \cdot 0$ & 4.9 & $3-9$ & 3.4 & $4 \cdot 1$ \\
\hline & $7 \cdot 1$ & 5.9 & $5 \cdot 8$ & $4 \cdot 5$ & $6 \cdot 1$ & $4-0$ & $4 \cdot 0$ & $5 \cdot 1$ \\
\hline & $7 \cdot 7$ & $5 \cdot 2$ & $6 \cdot 2$ & $5 \cdot 0$ & $4 \cdot 0$ & $5 \cdot 0$ & $6 \cdot 3$ & $5 \cdot 3$ \\
\hline & $8 \cdot 3$ & 6.5 & $9 \cdot 0$ & $5 \cdot 1$ & 6.8 & $9 \cdot 8$ & 9.0 & 7.7 \\
\hline & 8.9 & $9 \cdot 5$ & $8 \cdot 9$ & $6 \cdot 2$ & $8 \cdot 0$ & $9 \cdot 0$ & $8 \cdot 8$ & $8 \cdot 4$ \\
\hline & $9 \cdot 5$ & $10 \cdot 6$ & $11 \cdot 1$ & $6 \cdot 4$ & $8 \cdot 1$ & $10 \cdot 0$ & $10 \cdot 1$ & $9 \cdot 4$ \\
\hline & Mean & $6 \cdot 3$ & $6 \cdot 6$ & $4 \cdot 3$ & $5 \cdot 6$ & $6 \cdot 1$ & $6 \cdot 2$ & \\
\hline & SEM & & & & 0.61 & & & \\
\hline \multirow[t]{9}{*}{ Apparent $N$ digestibility } & $5 \cdot 9$ & 0.83 & -- & - & - & -- & - & 0.83 \\
\hline & $6 \cdot 5$ & $0 \cdot 86$ & $0 \cdot 87$ & $0 \cdot 81$ & $0 \cdot 81$ & 0.86 & $0 \cdot 86$ & 0.85 \\
\hline & $7 \cdot 1$ & $0 \cdot 85$ & 0.86 & 0.81 & $0 \cdot 80$ & 0.86 & $0 \cdot 86$ & 0.84 \\
\hline & $7 \cdot 7$ & 0.86 & $0 \cdot 86$ & 0.83 & 0.79 & 0.86 & 0.86 & 0.84 \\
\hline & $8 \cdot 3$ & 0.87 & 0.86 & 0.82 & 0.80 & $0 \cdot 85$ & 0.87 & 0.85 \\
\hline & $8 \cdot 9$ & 0.87 & 0.86 & 0.82 & 0.80 & 0.85 & 0.87 & 0.85 \\
\hline & $9 \cdot 5$ & $0 \cdot 88$ & $0 \cdot 86$ & 0.81 & $0 \cdot 81$ & 0.85 & 0.88 & 0.85 \\
\hline & Mean & $0 \cdot 86$ & $0 \cdot 86$ & 0.82 & 0.80 & $0 \cdot 85$ & $0 \cdot 87$ & 0.83 \\
\hline & SEM & & & & 0.016 & & & \\
\hline
\end{tabular}

* Lupinus augustifolius. 
Table 5. Utilization of lysine (relative to free lysine)

(Mean values and standard deviations)

\begin{tabular}{|c|c|c|c|c|c|c|}
\hline & \multicolumn{2}{|c|}{ Wt gain } & \multicolumn{2}{|c|}{$\begin{array}{c}\text { Feed conversion } \\
\text { ratio }\end{array}$} & \multicolumn{2}{|c|}{$\begin{array}{l}\text { Nitrogen } \\
\text { retention }\end{array}$} \\
\hline & Mean & SD & Mean & SD & Mean & $\mathrm{SD}$ \\
\hline \multicolumn{7}{|l|}{ Expt 1} \\
\hline Soya-bean meal & 0.95 & 0.076 & 0.95 & 0.095 & & \\
\hline Cotton-seed meal & 0.75 & 0.063 & 0.80 & 0.096 & & \\
\hline Meat meal 1 & 0.86 & 0.091 & 0.88 & 0.093 & & \\
\hline Meat meal 2 & 0.88 & 0.080 & 0.90 & $0 \cdot 103$ & & \\
\hline \multicolumn{7}{|l|}{ Expt 2} \\
\hline Soya-bean meal & 0.99 & 0.040 & $1 \cdot 00$ & $0 \cdot 101$ & 0.85 & 0.073 \\
\hline Cotton-seed meal & 0.69 & 0.054 & 0.61 & 0.111 & 0.64 & 0.071 \\
\hline Meat meal & $0 \cdot 88$ & 0.046 & $0 \cdot 89$ & $0 \cdot 101$ & $0 \cdot 76$ & 0.060 \\
\hline Lupins* & 0.90 & 0.044 & 0.86 & $0 \cdot 106$ & 0.90 & $0 \cdot 064$ \\
\hline Milk & 0.99 & 0.034 & 0.93 & $0 \cdot 111$ & 0.91 & 0.071 \\
\hline
\end{tabular}

* Lupinus augustifolius.

\section{DISCUSSION}

Lysine is known to be the first limiting amino acid in cereal-based concentrate diets. This limitation can be overcome by the inclusion of free lysine or protein concentrates. However, the availability of lysine in the protein concentrates has been shown to vary with the source of protein in growing pigs (Batterham et al. 1979).

There have been numerous estimates of lysine digestibility on growing pigs both in the whole digestive tract (e.g. Poppe, 1976) and to the end of the small intestine (e.g. Low, 1979; Alimon \& Farrell, 1980). However, as most amino acids that are hydrolysed in the large intestine are not used by the pig for protein synthesis, digestibility determined at the end of the small intestine should be a more accurate indicator of the amino acids available for use by the pig.

The apparent digestibility of lysine to the ileum has been shown to be higher for soya-bean meals $(84-87 \%$ ) than for cotton-seed meals (61-67\%) and meat meals (53-70\%) (Tanksley \& Knabe, 1984). Lower estimates were made by Zebrowska \& Buraczewski (1977) for the apparent digestibility of lysine to the terminal ileum, of soya-bean meal $(81 \%)$ and meat meal $(58 \%)$, while a value of $77 \%$ for meat meal was reported by Alimon \& Farrell $(1980)$. These differences may be due to the large range in quality of meat meals and meat-and-bone meals as prepared commercially (Leibholz, 1979).

In the only experiment with young pigs ( $23-51 \mathrm{~d}$ of age) the apparent digestibility of lysine to the last one-third of the small intestine was $54 \%$ for meat meal, $62 \%$ for cotton-seed meal and $73 \%$ for peanut meal (Leibholz, 1985). These values show the same trend as the results with growing pigs $(30-60 \mathrm{~kg}$ live weight).

In growing pigs ( $20-45 \mathrm{~kg}$ live weight) the availability of lysine measured by a slope-ratio assay was estimated to be $50 \%$ for meat meal, $39 \%$ for cotton-seed meal and $87 \%$ for soya-bean meal when carcass gain was considered as the criterion of response (Batterham et al. 1979).

In the present experiment, relative utilization of lysine for growth of young pigs was found to be $0.86-0.88 \%$ for meat meal, $0.69-0.75 \%$ for cotton-seed meal and $0.95-0.99 \%$ for soya-bean meal by comparing the slope of the growth response with that for free lysine. 
The higher values obtained from these growth studies compared with the digestibility values may be explained partially by the low apparent digestibility estimates obtained in the whole ileum (Leibholz, 1985) rather than in the terminal ileum. Also, in the experiment of Leibholz (1985) comparisons were made between protein concentrates; the apparent digestibility of lysine to the ileum for the control diet of wheat and skim milk was 0.70 . In the present experiment, lysine utilization from protein concentrates was compared with that of free lysine, which was considered to be $1 \cdot 00$.

From the present results it may be concluded that differences in the utilization of lysine between protein concentrates appear to be smaller in young pigs than in growing pigs (Batterham et al. 1979). However, the lower utilization of lysine from cotton-seed meal and meat meal compared with soya-bean meal and other protein concentrates shows the same trend as in the values from growing pigs.

The apparent digestibility to the ileum of lysine in lupins was 0.75 (Leibholz, 1985) while its utilization for weight gain was 0.90 . This does not agree with an estimate for the availability of lysine of 0.57 in one type of lupin by Batterham et al. (1984) but the lysine in other types of lupin given in the same experiment did have a higher availability. This may be explained by the low methionine content of some lupins.

In the present experiment, all diets contained at least $30 \%$ more than the US National Research Council (1979) requirements for all essential amino acids except lysine.

In general, there was a linear response to lysine supplementation of the diets to the highest level of inclusion of lysine, $10.1 \mathrm{~g} / \mathrm{kg}$ in Expt 1 and $9.5 \mathrm{~g} / \mathrm{kg}$ in Expt 2. This suggests that the lysine requirement of pigs from 21 to $49 \mathrm{~d}$ of age may be greater than the minimum requirement of $9.5 \mathrm{~g}$ lysine $/ \mathrm{kg}$ diet suggested by the US National Research Council (1979). However, the UK Agricultural Research Council (1981) recommendation for lysine for pigs of this age is about $14 \mathrm{~g} / \mathrm{kg}$ of the present diet which has been calculated to contain $14 \mathrm{MJ}$ $\mathrm{DE} / \mathrm{kg}$. It is obvious that further work is required to determine the lysine requirement of young pigs. The range of results in the literature may be partially explained by the diets fed, in particular, the availability of lysine in the basal diets.

The crude protein $(\mathrm{N} \times 6.25)$ content of the diet increased from a basal level of $185 \mathrm{~g} / \mathrm{kg}$ diet to $255 \mathrm{~g} / \mathrm{kg}$ diet. The basal diet contained less crude protein than the published requirement of $200 \mathrm{~g} / \mathrm{kg}$ for pigs of this age (US National Research Council, 1979). However, as already mentioned, the US National Research Council (1979) requirements for all essential amino acids were met in all diets. The linear response to lysine supplementation would tend to confirm that lysine was the first limiting amino acid. Also, it has been assumed that all the lysine from the free lysine supplement was available as this was used as the reference slope for the assay of lysine utilization.

In the present experiment, increasing the lysine content from 73 to $106 \%$ of the requirements of the pigs of this age (US National Research Council, 1979) increased the weight gains of young pigs from 89 to $317 \mathrm{~g} / \mathrm{d}$ or $256 \%$. Batterham et al. (1979) increased the lysine content of the diet of growing pigs from 74 to $110 \%$ of their requirements (US National Research Council, 1979) and the weight gains of the pigs increased from 384 to $547 \mathrm{~g} / \mathrm{d}$ or $42 \%$. The greater response in weight gain to lysine supplementation in the present experiment may be due to a greater sensitivity of the younger pigs to amino acid deficiencies than older pigs. Also, in the present experiment the pigs were fed ad lib. while in the experiments of Batterham et al. (1979) they were restricted to $50 \mathrm{~g} / \mathrm{kg}$ live weight per d.

In conclusion, the relative utilization of lysine from nine protein concentrates varied from 0.61 to 1.00 for weight gain, feed conversion ratio and $\mathrm{N}$ retention when compared with the utilization of free lysine when all diets were given $a d$ lib. The utilization of lysine from cotton-seed meal was significantly less than the utilization of free lysine. 


\section{REFEREN CES}

Agricultural Research Council (1981). The Nutrient Requirements of Pigs. Slough: Commonwealth Agricultural Bureaux.

Alimon, R. \& Farrell, D. J, (1980). Australian Journal of Agricultural Research 31, 627-635.

Batterham, E. S., Murison, R. D. \& Anderson, L. M. (1984). British Journal of Nutrition 51, 85-99.

Batterham, E. S., Murison, R. D. \& Lewis, C. E. (1979). British Journal of Nutrition 41, 383-391.

Kendall, M. \& Stuart, A. (1977). The Advanced Theory of Statistics, vol. 1. New York: Charles Griffin \& Co.

Leibholz, J. (1979). Animal Feed Science and Technology 4, 53-61.

Leibholz, J. (1985). British Journal of Nutrition 53, 615-624.

Low, A. G. (1979). British Journal of Nutrition 41, 147-156.

National Research Council (1979). Nutrient Requirements of Domestic Animals no. 2. Nutrient Requirements of Swine, 8th ed. Washington, DC: National Academy of Sciences.

Poppe, S. (1976). European Association for Animal Production publication no. 16, 369-378.

Steel, R. G. D. \& Torrie, J. H. (1960). Principles of Statistics. New York: McGraw-Hill Book Co.

Tanksley, D. \& Knabe, D. A. (1984). In Recent Advances in Animal Nutrition-1984, p. 75 [W. Haresign and D. J. A. Cole, editors]. London: Butterworth.

Zebrowska, T. \& Buraczewski, S. (1977). Proceedings of the 2nd International Symposium on Protein Metabolism and Nutrition, pp. 82-85. Wangenigen, The Netherlands: Centre for Agricultural Publishing and Documentation. 